\title{
Sir George Andreas Berry, LL.D., F.R.C.S.E.
}

Sir George Berry died at his residence, “King's Knoll," North Berwick, on June 18 , I940, in his eighty-seventh year.

George Andreas Berry was the eldest son of Walter Berry of Glenstriven, Argyllshire. Born in 1853 , he was educated at Marlborough and at Edinburgh. He studied Mathematics under Professor P. G. Tait, and became one of the six members of Tait's Senior Class, where he developed his remarkable knowledge of this subject. He graduated M.B., C.M., at Edinburgh in I876. In I88 I he became a Fellow of the Royal College of Surgeons of Edinburgh.

Before beginning practice, George Berry prosecuted his special studies in Ophthalmology for some years in various universities and hospitals. In Copenhagen he worked with his distinguished uncle, Professor Hansen Grut; and he also studied in France, Austria, Germany, and Holland at this period of his career.

While he was Resident House Surgeon at Moorfields Eye Hospital, London, in $1878-79$, Berry was one of the moving spirits in the formation of the Ophthalmological Society of the United Kingdom, which was founded in 1880 . Throughout his lifetime he took the greatest interest in this Society, of which he was an Original Member.

While still a comparatively young man he was recognised as an authority in Ophthalmology, and enjoyed a high reputation on the Continent and in America, as well as at home. He was the author of a text-book entitled: Diseases of the Eye-A Practical Treatise for Students of Ophthalmology. This text-book was referred to by many of the leading Continental professors of Ophthalmology as being not only an exhaustive treatise, but also distinguished by many original observations and ideas. It was widely used as a standard work for many years after its publication. The terms of the dedication of this book to Edmund Hansen Grut, M.D., show the keen appreciation, the enthusiasm, and the loyalty which were essentially characteristic of Berry. All his assistants, and many others who had the privilege to know him, recognised the magnetism of his personality, the strength of his intellect, and his independent and original type of mind.

Two monographs from his pen were also much appreciated and widely used: Subjective Symptoms in Eye Disease and Ophthalmoscopic Diagnosis. That on subjective symptoms, published in I886, was 
especially interesting and characteristic. His interest in, and remarkable knowledge of, the significance of subjective symptoms in the early diagnosis of disease proved of great value in his clinical work and teaching, which was not only instructive to all, but stimulating and inspiring to his senior students and assistants.

He was a well-known figure at the meetings of the Ophthalmological Society of the United Kingdom, and was President from Igog to I9I I. In 1917 the Society paid him the highest honour by electing him to be Bowman Lecturer. His important contributions in discussion and his able and numerous papers which appeared in the Society's Transactions, and also elsewhere, give evidence alike of his ability, and of the lively interest which he always took in the advance of Ophthalmology.

He was a member of the British Medical Association for many years. He was awarded the Middlemore Prize in 1886 , and was Vice-president of the Section of Ophthalmology in I889 and I898, and President in 1905.

Berry served on the staff of the Eye Department of the Royal Infirmary, Edinburgh, for twenty-three years, and retired from the position of Senior Surgeon of the Department in 1905. As Lecturer on Diseases of the Eye in the University of Edinburgh he was responsible for the training of many students, not a few of whom have obtained distinction as oculists at home and in Overseas Dominions.

He became a Fellow of the Royal Society of Edinburgh in I893, in which year he contributed "A Note on the Focus of Concavo-Convex Lenses the surfaces of which are of Equal Curvature" (Proc. Roy. Soc. Edin., vol. xx, 1893, pp. 192-195). He was a Member of Council of the Society from I916 to 1919, and Vice-President from I919 to 1922.

Berry was an Honorary Fellow of the Royal Academy of Medicine of Ireland; President of the Royal College of Surgeons of Edinburgh from I9IO to I9I2; a Member of the Edinburgh University Court from I9I I to 1923; and a Manager of the Royal Infirmary. During the last war he established and conducted the Ophthalmic Department of the Second Scottish General Hospital, Edinburgh. He was appointed Honorary Surgeon Oculist in Scotland to H.M. King Edward VII and to H.M. King George V, and in I9I6 the honour of knighthood was conferred upon him. From 1922 to I93 I he was Member of Parliament (Conservative) for the Scottish Universities, and at the end of this period he received the Honorary LL.D. of Edinburgh University.

Sir George Berry was a man of remarkable ability. Physically vigorous, he enjoyed outdoor sports-especially golf and angling. $\mathrm{He}$ was much interested in music and played the 'cello. He took a prominent part in relation to the Foundation of the Reid Chair of Music in the 
University of Edinburgh. His great interest in mathematics was abundantly shown in his text-book and in his contributions to this subject. He possessed a remarkable acquaintance with modern languages and especially with the less generally known Norse tongues, with which he had become familiar in early life. His brightness of mind, his scientific imagination, and high and varied attainments were fully recognised and highly valued by his colleagues, and he was much beloved by a wide circle of friends.

When he retired from a long life of high attainment and great activity he resided at North Berwick, where he had built a house and laid out an excellent garden, in which he took great pleasure. He married, in 1883 , Agnes Jean, daughter of the late Sir William Muir, K.C.S.I., by whom he was predeceased; and is survived by three daughters.

A. H. H. S. 